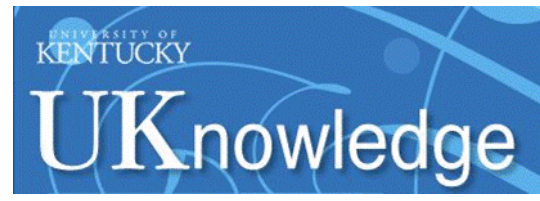

University of Kentucky UKnowledge

2012

\title{
The Pharmacokinetics and Toxicology of Aluminum in the Brain
}

Robert A. Yokel

University of Kentucky, ryokel@email.uky.edu

Right click to open a feedback form in a new tab to let us know how this document benefits you. Follow this and additional works at: https://uknowledge.uky.edu/ps_facpub

Part of the Pharmacy and Pharmaceutical Sciences Commons 


\section{The Pharmacokinetics and Toxicology of Aluminum in the Brain}

Digital Object Identifier (DOI)

http://dx.doi.org/10.2174/1877944111202010054

\section{Notes/Citation Information}

Published in Current Inorganic Chemistry, v. 2, no. 1, p. 54-63.

(c) 2012 Bentham Science Publishers

This article is available to download for free under the Open Access Plus program of Bentham Science in which the content is published under the creative commons license CC BY -NC -ND 4.0 


\title{
The Pharmacokinetics and Toxicology of Aluminum in the Brain
}

\author{
Robert A. Yokel*
}

Department of Pharmaceutical Sciences College of Pharmacy 511C Multidisciplinary Sciences Building 725 Rose Street University of Kentucky Academic Medical Center Lexington, KY, 40536-0082

\begin{abstract}
The chemical forms (species) of aluminum in blood plasma and brain extracellular fluid are considered, as they are the candidates for brain aluminum uptake and efflux. The blood-brain barrier is the primary site of brain aluminum uptake. The mechanism of brain uptake of aluminum transferrin, long thought to be mediated by transferrin-receptor mediated endocytosis, requires further investigation. Brain Al citrate uptake has been attributed to the sodium-independent Lglutamate/L-cystine exchanger system, system Xc-. Reports have suggested aluminum can compromise blood-brain barrier integrity, however the studies were conducted with aluminum concentrations greatly exceeding those seen in human blood plasma. Aluminum appeared in cerebrospinal fluid suggesting it can cross the choroid plexus and in brain after intranasal application suggesting it can be taken up by cranial nerves, but neither of these routes has been definitively demonstrated. Brain aluminum efflux appears to be carrier-mediated, however the mechanism has not been identified. A small increase in brain aluminum seems sufficient to produce neurotoxicity. Once aluminum enters the brain it persists there for a very long time; estimates of the half-life range from $20 \%$ of the lifespan to greater than the lifespan. Al persistence in bone, which maintains the majority of the body burden, may influence brain Al, due to equilibrium among the body's organs. Chelation therapy with desferrioxamine has been shown to reduce some manifestations of aluminum toxicity although it may increase redistribution of aluminum to the brain to increase aluminum-induced neurotoxicity. An orally-effective aluminum chelator that is an improvement over desferrioxamine has not yet been demonstrated. Although a non-essential metal, there are mechanisms enabling aluminum to get into the brain, accumulating over the lifespan, and creating the potential to contribute to many neurodegenerative disorders.
\end{abstract}

Keywords: Aluminum, blood-brain barrier, brain efflux, brain influx, chelation, choroid plexus.

\section{INTRODUCTION}

Aluminum (Al) is not known to serve any essential function in the human, so one might consider its unintended presence in the body as having potential risk and no benefit. Its ability to produce neurotoxicity was demonstrated over 100 years ago [1]. Its potential to produce brain damage was well illustrated with the onset of dialysis encephalopathy (DES) during the onset of widespread hemodialysis. Some dialysis patients exposed to $\mathrm{Al}$ in the dialysis fluid or from receipt of oral Al-based phosphate binders developed a generalized brain dysfunction, leading to seizures and fatality [2]. The safety of $\mathrm{Al}$ in the human has been controversial for a century, including its use in cookware and food storage. Further controversy developed when it was suggested A1 may be a neurotoxic factor in Alzheimer's disease (AD) [3]. Owing to the recognition of $\mathrm{Al}$ as a neurotoxicant, it is beneficial to understand the mechanisms of brain entry and exit, the residence time of $\mathrm{Al}$ in the brain, and factors that influence these endpoints, i.e., Al toxicokinetics. For humans who develop neurobehavioral signs and symptoms due to brain $\mathrm{Al}$ overload, or suspect they are suffering from $\mathrm{Al}$ intoxication, it is useful to know potential diagnostic and treatment approaches to Al overload. This review focuses on Al toxicokinetics in the brain and chelation therapy to diagnose and treat $\mathrm{Al}$ overload.

*Address correspondence to this author at the Department of Pharmaceutical Sciences College of Pharmacy 511C Multidisciplinary Sciences Building 725 Rose Street University of Kentucky Academic Medical Center Lexington, KY, 40536-0082; Tel: 859-257-4855;

Fax: 859-257-7585; E-mail: ryokel@email.uky.edu

\section{THE CHEMICAL FORMS (SPECIES) OF ALUMI- NUM THAT MIGHT ENTER AND EXIT THE BRAIN}

Aluminum can occur in various chemical forms (species) in vivo, which have different physical, chemical and biological properties [4]. The toxicokinetics of $\mathrm{Al}$ is dependent on its chemical species. Based on thermodynamic modeling, and consistent with experimental observations, there are two primary $\mathrm{Al}$ species in blood extracellular fluid (ECF), i.e. plasma; Al transferrin (Tf) accounts for 93\% and Al citrate $\sim 5.5 \%$ [5], making them the primary candidates for brain $\mathrm{Al}$ uptake. Given the rapid formation of the $1: 1$ and $1: 2$ Al:citrate complexes and slow formation of the 1:3 complex at the low Al concentrations of blood plasma [5], the Al citrate species in blood available to enter the brain might be the $1: 1$ and/or $1: 2$ complex.

The concentration of $\mathrm{Tf}$ is very low in cerebrospinal fluid (CSF) $(<0.25 \mu \mathrm{M})$, and presumably brain ECF, compared to $30 \mu \mathrm{M}$ in blood plasma [6]. Furthermore, it has been suggested that there are no available binding sites for $\mathrm{Al}$ on $\mathrm{Tf}$ in brain ECF [7]. In contrast, the citrate concentration in brain ECF is higher than in plasma $(180$ vs. $99 \mu \mathrm{M})$. CSF pH is the same as blood plasma. These suggest that $90,5,4$, and $1 \%$ of $\mathrm{Al}$ in $\mathrm{CSF}$, and presumably brain ECF, is associated with citrate, hydroxide, Tf, and phosphate, respectively, according to calculations conducted by Harris [8]. As Al citrate is the predominant $\mathrm{Al}$ species in brain ECF, it is likely to be the Al species transported into brain cells from CSF and brain ECF or out of the brain. 
Because the free $\mathrm{Al}$ ion and its complexes with $\mathrm{Tf}$ and citrate are quite hydrophilic (the octanol/aqueous distributions are 0.0052 and 0.0019 , respectively), they would be expected to diffuse across membranes such as the bloodbrain barrier (BBB) at a rate comparable to sucrose, which is a very slow $\mathrm{BBB}$ permeant [9].

\section{THE SITES AND RATES OF BRAIN ALUMINUM UPTAKE}

\subsection{From the Blood Across the Blood-Brain Barrier}

$\mathrm{Al}$ is most often absorbed from the gastrointestinal tract or across the lungs into systemic circulation. Alternatively, there is evidence some metals can be taken up by exposed sensory nerves in the nasal cavity and possibly transported into the brain, as discussed below.

Patients who received brain surgery for a tumor after consuming an Al-rich antacid for 10 days had 2-fold higher brain Al concentration than patients who consumed an antacid low in $\mathrm{Al}$ [10], demonstrating oral Al absorption and distribution into the human brain in the presence of normal renal function. This was supported by similar findings in normal rats and rats with renal failure [11-14].

There are two routes by which Al might enter the brain from blood, 1) through the BBB, and 2) through the choroid plexus (CP) into the CSF of the ventricles within the brain and then into the brain. Aluminum can rapidly enter brain ECF and CSF, although its concentrations in these two fluids are less than in blood [15-18]. To assess the primary route of brain Al uptake, the flux of $\mathrm{Al}$ through the $\mathrm{BBB}$ and the $\mathrm{CP}$ was assessed by concurrent microdialysis of the rat's frontal cortex, a lateral ventricle, and a jugular vein. This was conducted with an i.v. injection of Al citrate at a dose that exceeded the capacity of $\mathrm{Tf}$ to bind $\mathrm{Al}$, therefore favoring $\mathrm{Al}$ citrate as the Al species most likely to circulate in blood and be available to enter the brain. Dialysate Al concentration from the cortex peaked in the first 5 min sample and was higher than from the lateral ventricle [15]. The rapid appearance of $\mathrm{Al}$ in the frontal cortex was attributed to brain $\mathrm{Al}$ entry through the $\mathrm{BBB}$ rather than through the $\mathrm{CP}$ into $\mathrm{CSF}$ and then diffusion into the brain. This was concluded based on the following points: 1) the $\mathrm{Al}$ concentration was lower in the CSF than in the frontal cortex, 2) Al diffusion from a lateral ventricle into the brain would be against bulk CSF flow within brain parenchyma to lateral ventricles [19], and 3) some frontal cortical regions in the rat are $1.5 \mathrm{~mm}$ from a lateral ventricle and $1 \mathrm{~mm}$ from the subarachnoid space. This distance was thought to be too great for Al to diffuse from CSF to the frontal cortex within $5 \mathrm{~min}$. The $\sim 100$ - to 1000 fold greater surface area of the BBB microvessels than the vasculature perfusing the $\mathrm{CP}$ make the $\mathrm{BBB}$ the more likely portal of brain Al entry. It was further concluded that Al entered the brain by a carrier-mediated process. The rate of $\mathrm{Al}$ citrate flux through a membrane by diffusion was estimated to be $4 \times 10^{-16} \mathrm{~mol} \mathrm{~cm}^{-2} \mathrm{sec}^{-1}$ [20]. Brain capillary surface area has been estimated to be $240 \mathrm{~cm}^{2} / \mathrm{g}$ brain [21]. Brain ECF occupies $~ 15 \%$ of brain volume. The unbound plasma $\mathrm{Al}$ concentration after the i.v. injection of $\mathrm{Al}$ citrate was estimated to be $\sim 1 \mathrm{mM}$ based on the Al concentration $(\sim 30$ $\mu \mathrm{M})$ in the dialysate from microdialysis probes in the jugular vein [15] and a relative recovery, using microdialysis, of Al from plasma ultrafiltrate of $3.25 \%$. If $4 \times 10^{-16}$ mole of $\mathrm{Al}$ diffuses through $1 \mathrm{~cm}^{2}$ of membrane/sec, then $\sim 3 \times 10^{-11}$ mole of Al could diffuse through $240 \mathrm{~cm}^{2}$ of capillary endothelial cells into 1 gram of brain in $5 \mathrm{~min}$. Assuming the latter amount of $\mathrm{Al}$ distributed throughout brain $\mathrm{ECF}$, the $\mathrm{Al}$ concentration would be $\sim 2 \times 10^{-17} \mathrm{M}$, producing a brain/ blood ratio of 0.0002 . However, the brain/blood ratio seen 5 min after this i.v. injection of Al citrate was 0.15 [15], suggesting Al citrate brain uptake is carrier mediated.

The influx transfer coefficient $\left(\mathrm{K}_{\text {in }}\right)$ for $\mathrm{Al}$ has been reported in two non-peer-reviewed reports. For the free $\mathrm{Al}$ ion it was reported to be $\sim 1000 \times 10^{-5} \mathrm{~mL} / \mathrm{sec} / \mathrm{g}$; in the presence of $\mathrm{Tf}$, that would maximally bind $40 \%$ of the Al, it was $300 \times 10^{-5} \mathrm{~mL} / \mathrm{sec} / \mathrm{g}$ [22]. In contrast, a much lower value $(\sim$ $0.035 \times 10^{-5} \mathrm{~mL} / \mathrm{sec} / \mathrm{g}$ ) was reported in a second study, which was based on quite variable results after a $50 \mathrm{~h} \mathrm{Al}$ perfusion [23]. The procedures used in both of these studies may have underestimated $\mathrm{K}_{\mathrm{in}}$ because they did not account for potential brain Al efflux. The first utilized a $45 \mathrm{sec}$ washout that followed brain Al perfusion. The second employed a $50 \mathrm{~h}$ infusion. The former values, when compared to the brain capillary diffusion rate of sucrose $\left(2.9 \times 10^{-5} \mathrm{~mL} / \mathrm{sec} / \mathrm{g}\right)$ [9], support the conclusion of carrier-mediated brain Al uptake.

Studies in which rats were i.v. or i.p. injected with $\mathrm{Al}$ citrate, Al chloride or Al-Tf resulted in 0.0008 to $0.009 \%$ of the Al dose/g brain [15, 24-26]. These results show that the extent of brain Al uptake is low. The percentage of the dose of $\mathrm{Al}$ injected s.c. into pregnant rats on gestation day 15 was 0.0067 and $0.0002 \%$ in maternal and fetal brain, respectively, 5 days later [27], demonstrating the ability of Al to cross the placenta and fetal BBB.

\section{THE MECHANISMS OF BRAIN ALUMINUM UP- TAKE}

The barrier properties of the BBB are primarily attributed to the tight junctions between opposing plasma membranes of the endothelial cells that comprise the microvessels that perfuse the brain, greatly limiting paracellular diffusion [28]. Contributing to this barrier are two additional properties of these endothelial cells; 1) the nearly total absence of fenestrations through which substances might diffuse and 2) the low rates of fluid phase endocytosis that might engulf $\mathrm{Al}$ in the blood and internalize it. Further membrane barriers are provided by the following; (i) a basement membrane that surrounds the brain microvascular endothelial cells (BMECs), (ii) pericytes that surround $\sim 30 \%$ of the endothelial abluminal cell surface, and (iii) astrocyte foot processes that cover $>90 \%$ of the surface of the endothelial cells and pericytes [29]. The BMECs are extensively distributed throughout the brain, so that every brain cell is within $\sim 30$ to $50 \mu \mathrm{m}$ of a blood supply, providing very rapid exchange of substances between blood and brain cells (Arnold Scheibel, personal communication). This anatomy can be seen in many of the figures of the human cerebellum published by Duvernoy et al. [30] and in mouse cortex (Fig. 2B of [31]).

Mechanisms of brain uptake include diffusion and carrier mediated transport. As noted above, paracellular diffusion through the BBB is greatly limited, if not prevented. Diffusion through $\mathrm{BBB}$ membranes greatly decreases as size ex- 
ceeds $\sim 400$ daltons and favors lipophilic substances [31]. Many transporters are expressed at the BBB [31]. Some mediate brain uptake, others prevent brain uptake, and some are bidirectional. Some are equilibrative. Some are energydependent that are able to move substrates unidirectionally and against a concentration gradient. There are receptormediated mechanisms which may operate by facilitated diffusion and are often bidirectional [31]. An example of metal species-specific transport at the BBB is the large neutral amino acid transporter that facilitates brain influx of the methylmercury L-cysteine complex, which is perhaps mistaken for the structurally similar L-methionine [32].

The Al-Tf complex was shown to bind to (be taken up by) IMR 32 and C1300 neuroblastoma cells with an equilibrium constant and uptake half-life $\left(t_{1 / 2}\right)$ similar to the iron (Fe)-Tf complex [33, 34]. Uptake of Al following Al-Tf exposure has been shown with non-CNS cells, and was generally greater than from Al citrate [35-41]. Using whole brain homogenate, the binding of Al-Tf was shown to have a lower affinity than Fe-Tf, but was quite high, leading the authors to suggest $\mathrm{Tf}$ and its receptor may enable brain $\mathrm{Al}$ access [42]. Oligodendrocytes took up more $\mathrm{Al}$ as $\mathrm{Al}$-Tf than $\mathrm{Al}$ citrate or the $\mathrm{Al}$ ion (introduced as the chloride) [43]. These results suggested Al might enter the brain via transferrin-receptor mediated endocytosis (TfR-ME).

Based on the rate of TfR-ME of Fe into the brain $\left(\mathrm{K}_{\text {in }}=\right.$ $0.08 \times 10^{-5} \mathrm{~mL} / \mathrm{sec} / \mathrm{g}$ ), the blood $\mathrm{Al}$ concentration from its injection to the time of brain harvest, and assuming that AlTf was cleared from blood to brain over the four $h$ by a first order process, TfR-ME could account for the observed brain influx of $\mathrm{Al}$ (above). The contribution of TfR-ME to brain $\mathrm{Al}$ uptake is consistent with the positive correlation between $\mathrm{Al}$ concentration in cortical and hippocampal neurons and the density of TfRs [44]. However, the affinity of TfR 1 for the Al-Tf complex was found to be very weak in vitro, leading Hémadi et al. to caution that $\mathrm{Al}$ transfer from blood to cell cytoplasm may not follow the TfR-ME pathway [45]. In another report from the same laboratory Ha-Duong et al. found no interaction between Al-Tf and the TfR [46]. Based on structural and physicochemical characteristics of apo-Tf, Fe-Tf, Al-Tf and the TfR (diffusion coefficient, hydrodynamic radius, capillary electrophoretic mobility, and zeta potential) and calculation of acidic amino acid residues, Sakajiri et al. concluded that the driving force for the formation of a complex of metal and the TfR is the electrostatic interaction between the negative charge of the former and positive charge of the latter. Because the Al-Tf complex surface charge is nearly the same as apo-Tf, and less negative than Fe-Tf, they suggested formation of an Al-Tf and TfR complex is not possible [47].

Several groups have reported that Al-Tf reduces brain Fe uptake. Studies to elucidate the mechanism of this found that the Al-Tf complex reduced the level of TfR mRNA in human erythroleukemia (K562) cells and the density of surface Tf binding sites on oligodendrocytes [35, 43]. However, a more recent report failed to find an effect of Al-Tf on TfR mRNA levels, TfR surface antigenic sites, or total TfR (membrane plus cytoplasm) quantity [41]. The latter results suggested Al-Tf was acting on sites other than the TfR to modulate Fe uptake. Therefore, it appears that the long held assumption that TfR-ME plays a role in mediating brain $\mathrm{Al}$ uptake may not be true. This requires further investigation.

There is evidence for a mechanism transporting $\mathrm{Al}$ citrate across the BBB. Brain Al uptake in the presence of Tf was lower than in its absence [22]. There was a lack of significant difference in brain Al uptake in hypotransferrinemic vs. control mice and after treatment with a TfR antibody in mice infused with $\mathrm{Al}$ citrate [48].

Given that the coordination binding of $\mathrm{Al}$ to citrate involves two carboxylates and the hydroxyl group, leaving a terminal carboxylate group unbound at physiological $\mathrm{pH}[49$, 50], it was hypothesized that the monocarboxylate transporter (MCT) mediates Al citrate distribution across the BBB. Introduction of 2,4-dinitrophenol (a metabolic inhibitor), pyruvate (a competitive substrate for the MCT), mersalyl (an MCT inhibitor), carbonyl cyanide $p$-trifluoromethoxyphenyl-hydrazone (FCCP, a proton ionophore that should reduce the proton gradient required by the MCT for substrate transport), and a decrease of proton availability on the brain side of the BBB all produced results consistent with the hypothesis [51, 52]. To further assess the hypothesis studies were conducted with rat erythrocytes, which express MCT-1 and the anion exchanger. The results did not show significant uptake of Al citrate into erythrocytes [53]. To investigate the properties of the carrier mediating Al citrate brain uptake, studies were conducted with an immortalized murine BBB endothelial cell line. The results suggested $\mathrm{Al}$ citrate uptake was energy dependent, ATP- but not Na/K-ATPase-dependent, and not a substrate for a dicarboxylate carrier or the $\alpha$-ketoglutarate exchanger. Its uptake was inhibited by numerous compounds, most of which are MCT substrates or inhibitors [53]. These results and the properties of the organic anion transporting polypeptide (oatp) family suggested it as a candidate. Al citrate weakly inhibited the uptake of an organic anion transported substrate in oocytes expressing rOAT3, suggesting it may be a substrate of an organic anion transporter (B. Feng, K.M. Giacomini \& Yokel, unpublished observations).

Magnesium D-aspartate was found to reduce brain Al accumulation following Al L-glutamate administration [54]. As D-aspartate is a substrate for glutamate transporters, it was suggested that it might cause the counter-transport of $\mathrm{Al}$ citrate. Investigating this hypothesis it was found that $\mathrm{Al}$ citrate uptake into an immortalized rat BBB endothelial cell line was inhibited by ligands for the sodium-independent Lglutamate/L-cystine exchanger system $\mathrm{Xc}^{-}$. Aluminum citrate uptake was increased into cells loaded with these ligands, suggesting a trans-stimulatory effect. These results suggest that system $\mathrm{Xc}^{-}$may mediate $\mathrm{Al}$ citrate uptake into the brain across the BBB [55].

\section{THE EFFECTS OF ALUMINUM ON THE BLOOD- BRAIN BARRIER}

There have been many studies assessing the potential of $\mathrm{Al}$ to compromise BBB function. Most were conducted utilizing conditions and $\mathrm{Al}$ concentrations that are not relevant to humans. Following the i.p. injection of $\mathrm{Al}$ chloride or $\mathrm{Al}$ lactate, often $100 \mathrm{mg} \mathrm{Al} / \mathrm{kg}$ or greater, the brain concentration of BBB markers increased [56-60]. This dose is 1000- 
fold greater than the average daily oral $\mathrm{Al}$ intake by humans. Considering that oral $\mathrm{Al}$ bioavailability is $\sim 0.3 \%$ and assuming $100 \%$ absorption of $\mathrm{Al}$ from the peritoneal cavity during this time, this dose would be expected to produce blood Al levels that far exceed those relevant to typical $\mathrm{Al}$ intake by humans. In vivo studies with bovine BMECs suggested $\mathrm{Al}$ interacts with the cell membrane surface [61]. Acellular studies suggested $\mathrm{Al}$ perturbation of membrane structure, perhaps due to its competition for $\mathrm{Ca}$ binding, production of vesicle fusion, and membrane rigidification [62].

The i.p. injection of $100 \mathrm{mg} \mathrm{Al} / \mathrm{kg}$ (as chloride) resulted in a dose-dependent increase of brain uptake of ${ }^{125} \mathrm{I}-\mathrm{N}-\mathrm{Tyr}-$ delta-sleep-inducing peptide and ${ }^{125} \mathrm{I}-\beta$-endorphin 1 and $2 \mathrm{~h}$ later $[63,64]$. Efflux of the ${ }^{125}$ I-labelled proteins Tyr-MIF (Tyr-Pro-Leu-Gly-amide) and enkephalins from the brain after their intracerebroventricular injection was inhibited by i.p. injection of $\mathrm{Al} 100 \mathrm{mg} \mathrm{Al} / \mathrm{kg}$ (as chloride), whereas efflux of technetium pertechnetate, albumin and D-Tyr-MIF-1 was not [65]. Reviewing their results, Banks and Kastin concluded that Al increased transmembrane diffusion and selectively altered saturable transport systems [66]. Subcutaneous injection of $100 \mu \mathrm{g} \mathrm{Al} / \mathrm{kg}$ (as chloride hexahydrate) reduced brain influx and efflux of quinidine (a cation) and reduced aspirin (an anion) efflux from the brain without affecting its influx [67]. Studies exposing goat BMECs to $\mathrm{Al}$ at a concentration at least 10 -fold greater than the threshold for clinical concern [68] produced alterations in the biophysical and biochemical properties of the BBB. These results suggest Al could alter flux of agents across the BBB, disrupting brain chemistry. However, considering the very large dose of $\mathrm{Al}$ used in these studies, the relevance of the findings to human exposure is questionable.

\section{FROM THE BLOOD ACROSS THE CHOROID PLEXUS}

\subsection{The Choroid Plexus and its Transporters}

There is a CP in each of the two lateral, the third, and the fourth ventricles of the brain. They have a monolayer of epithelial cells that, like the BBB, have tight junctions, and express many carriers. They are the sites of production of most of the CSF. Substances that cross the CP from blood enter the CSF. The ability of Al to distribute into the CSF from blood was demonstrated by the presence of measurable $\mathrm{Al}$ in CSF within $30 \mathrm{~min}$ after its i.v. injection as either the chloride or sulfate salt $[17,69]$. However, as brain ECF Al concentration was greater than CSF Al concentration following i.v. Al administration [15], and a source of CSF is brain $\mathrm{ECF}$, it is possible that the $\mathrm{Al}$ seen in the CSF crossed the BBB rather than the CP. There are no peer-reviewed reports assessing the extent, rate, or mechanism of $\mathrm{Al}$ flux across the $\mathrm{CP}$ that lack the confounding factor of flux across the BBB.

The CSF Al concentration was reported to be $<1$ to 6 $\mu \mathrm{g} / \mathrm{L}$ in normal humans and those with Parkinson's disease and $\mathrm{AD}$, and somewhat higher $(3$ and $7 \mu \mathrm{g} / \mathrm{L})$ in three $\mathrm{Al}-$ intoxicated dialysis patients [6,70-72]. The Al appeared to be associated with citrate. As the Al concentration in serum was $\sim 25$-fold higher than in CSF, it appears that the CP does not allow free Al flux.

\section{ALUMINUM UPTAKE FROM THE NASAL CAV- ITY}

\subsection{Brain Aluminum Entry via the Olfactory and Tri- geminal Neurons}

The roof of the nasal cavity is the only site where the nervous system is directly exposed to the environment, as terminals of the olfactory and sensory branch of the trigeminal nerves. Uptake from the nasal cavity into the olfactory nerve, followed by retrograde axonal transport to the olfactory bulb and beyond, was shown in studies of the polio virus, colloidal silver-coated gold, manganese, rubidium, thallium, yttrium, perhaps nickel, $\sim 35-\mathrm{nm}{ }^{13} \mathrm{C}$ particles, and $~$ $30 \mathrm{~nm}$ agglomerates of manganese, and may occur for other metals [73-81]. The anatomy of this process was reviewed [82]. The olfactory neurons project into the mucus that covers the olfactory epithelial surface, enlarging into an olfactory knob that has ciliary extensions (the sites of odor receptors) and extensive endocytotic vesicles. Exogenous substances might be taken up from the nasal cavity by the odor receptors or by endocytosis. Olfactory nerve axons can transport, by retrograde axonal transport, substances to the olfactory bulb, where they synapse with mitral and tufted cells, the secondary olfactory neurons. These latter cells can transport substances to the olfactory cortex, where they synapse on pyramidal cells, the tertiary olfactory neurons. Pyramidal cells have synaptic connections with pathways to multiple cortical and subcortical regions. These neuronal pathways provide a mechanism for distribution to multiple brain regions of exogenous substances that are able to cross synapses. Manganese uptake by the sensory branch of the trigeminal nerve within the nasal cavity has also been described [83]. Some of the distribution into the brain may have occurred by routes other than via the cranial nerves, such as through CSF or across the BBB. Although this route of uptake appears to deliver a very small percentage of drug or metal to the brain, it could be significant over a lifetime $[78,84]$. There is the potential for Al uptake via this route, however most airborne $\mathrm{Al}$ is in $\mathrm{Al}$ silicates which contain very little ionic, exchangeable $\mathrm{Al}$ [85].

To assess whether $\mathrm{Al}$ can enter the brain from the nasal cavity, Gelfoam ${ }^{\circledR}$ containing $0.5 \mathrm{~mL}$ of $15 \%$ Al lactate, $5 \%$ Al chloride, or $15 \%$ sodium lactate was implanted for one month into the nasal recess of rabbits [86]. Elevated Al and neuropathological changes were seen in the olfactory bulb, piriform cortex, hippocampus and cerebral cortex, but not in cerebellum, brainstem or spinal cord. These results suggested Al uptake from the nasal cavity and Al-induced pathology in pathways connected to the olfactory tract. However, concern was raised about the possibility that this prolonged exposure mechanically disrupted the olfactory epithelia [87]. Al uptake and granulomas in the piriform cortex, basal forebrain, hippocampus, and neocortex were also reported from a $75 \mathrm{mM}$ suspension of a lipophilic Al flavonol complex placed in the nasal cavity of the rabbit [88]. Compared to the typical urban air concentration of $1 \mu \mathrm{g} \mathrm{Al} / \mathrm{m}^{3}$ and inhalation of $20 \mathrm{~m}^{3} /$ day which is not necessarily all delivered through the nose and which is composed mostly of insoluble Al silicates, one must question the physiological relevance of this route of $\mathrm{Al}$ exposure. To further assess the possibility that Al can enter the brain from the nasal cavity, rats were 
nose-only exposed to aerosolized $\mathrm{Al}$ chlorohydrate and brain $\mathrm{Al}$ assessed [89]. A significantly greater $\mathrm{Al}$ concentration in the olfactory bulb was seen than in non-olfactory brain regions. Rats exposed to lipophilic Al acetylacetonate under conditions designed to maximize inhalation via the nasalolfactory system showed increased brain Al in the olfactory bulb, cortex, hippocampus, and entorhinal area. Elevated Al was also seen in the cerebellum, a structure which is not within, or directly connected neuronally to, the olfactory pathway [90], These data suggested that Al may have diffused through the CSF, rather than being transported through neurons.

\subsection{Brain Entry from the Nasal Cavity via the CSF Sur- rounding Cranial Neurons}

A second potential route of Al uptake from the nasal cavity is via the CSF in the perineural space surrounding the olfactory nerve. This has also been postulated as a route of brain prion uptake [91]. Aluminum diffusion by this route would be expected to initially result in distribution into CSF in the subarachnoid space and over the cortical surface.

\section{BRAIN ALUMINUM EFFLUX}

Evidence suggesting an Al efflux mechanism at the BBB was provided from results of studies in which Al was i.v. infused for sufficient time to achieve steady state Al concentrations in blood and brain ECF. An eight-fold range of infusion rates was used. The ratio of $\mathrm{Al}$ in the brain compared to the blood was $\sim 0.15$. If diffusion mediated transmembrane Al flux, then, (Al clearance into the brain from blood) $\mathrm{x}(\mathrm{Al}$ unbound concentration in blood ECF) should equal (Al clearance out of the brain) $\mathrm{x}$ (Al unbound concentration in brain ECF). As this ratio was much less than 1, it suggested that $\mathrm{Al}$ clearance out was greater than the clearance in, leading to the conclusion that brain Al efflux is mediated by a process other than diffusion [16]. The mechanism(s) mediating brain $\mathrm{Al}$ efflux has not been identified.

\section{BRAIN ALUMINUM CONCENTRATION AND DIS- TRIBUTION}

The concentration of $\mathrm{Al}$ in the brain is much lower than many other tissues, even in the presence of overt neurotoxicity. Increased brain Al concentrations of 4- to 6-fold in rabbits and somewhat higher increases in humans suffering from DES were associated with neurotoxicity [92-94]. Brain $\mathrm{Al}$ concentrations in victims of Creutzfeld-Jakob disease were not different from controls. As this neurodegenerative disorder is associated with widespread neuronal and glial pathology, it was concluded that brain damage alone does not result in elevated brain Al [95]. Similarly, brain Al was not elevated in 20 patients who died from liver disease or other complications of chronic alcoholism [96].

Based on a literature review of $\mathrm{Al}$ concentration in various brain regions Speziali and Orvini concluded that $\mathrm{Al}$ is generally higher in grey than white matter [97]. Using the Morin method to visualize Al, a positive fluorescence signal was detected in disintegrating neurofibrillary tangles and the senile plaque amyloid cores of non-demented elderly subjects. It was also seen in the wall of the capillary vessels of the $\mathrm{BBB}$, perivascular glial supporting tissues, nuclei of astrocytes, and nuclei and nucleoli of neurons in normal brain tissue [98].

\section{BRAIN ALUMINUM RESIDENCE TIME}

Most studies have reported a positive correlation between brain Al concentration and age [98-105]. This increase could be due to increased exposure with age, an increasingly leaky $\mathrm{BBB}$ with ageing, a decreased ability to remove Al from the brain with age (i.e., due to age-associated impaired kidney function), or very slow, or no, elimination of brain Al.

The rate of $\mathrm{Al}$ elimination from the entire organism may drive the rate of $\mathrm{Al}$ clearance from the brain, owing to the expected equilibrium among the compartments of Al storage. The skeletal system is the major compartment of Al storage, containing 58\% of the human Al body burden [106].

Aluminum persists for a very long time in rat brain following systemic injection of very small doses of ${ }^{26} \mathrm{Al}$. Rat brain ${ }^{26} \mathrm{Al}$ increased slightly from days 5 to 35 after an i.p. ${ }^{26} \mathrm{Al}$ injection [24], suggesting a lack of brain Al elimination. However, the possibility of ${ }^{26} \mathrm{Al}$ precipitation and delayed absorption from the peritoneal cavity, the small number of subjects, and the lack of a non- ${ }^{26} \mathrm{Al}$ dosed group to control for cross-contamination undermine confidence in these results. A subsequent study found no decrease in brain ${ }^{26} \mathrm{Al}$ concentration up to 270 days after ${ }^{26} \mathrm{Al}$ injection [107]. When ${ }^{26} \mathrm{Al}$ was given i.v. to rats that were euthanatized up to 256 days later, the $t_{1 / 2}$ of brain Al was estimated to be $\sim 150$ days [26]. Offspring of rats that were given ${ }^{26} \mathrm{Al}$ injections daily from day 1 to 20 postpartum were weaned on day 20 and sacrificed up to 730 days postpartum. Aluminum concentrations decreased over the 730 days in all tissues. At postpartum day 730 , brain ${ }^{26} \mathrm{Al}$ had decreased to $\sim 15 \%$ of that seen at weaning (day 20 postpartum) [108]. Calculation of the elimination $t_{1 / 2} \mathrm{~s}$ by the author of this review suggested they were $\sim 13$ and 1635 days in brain. There is little published information on allometric scaling of metal elimination rates that could be used to extrapolate these results from the rat to the human. 150 days is $\sim 20 \%$ of, and 1365 days exceeds, the rat's normal life span. For comparison, the wholebody $t_{1 / 2}$ of $\mathrm{Al}$ in the human was estimated to be 50 years [109]. As brain Al was not determined for at least $3 t_{1 / 2} \mathrm{~s}$ in the animal studies and the estimated whole-body $t_{1 / 2}$ of $\mathrm{Al}$ in the human is well beyond the study period, these estimated terminal $t_{1 / 2} \mathrm{~S}$ of brain $\mathrm{Al}$ are not expected to have a high degree of accuracy.

\section{CHELATION OF BRAIN ALUMINUM}

In initial uncontrolled studies, desferrioxamine (DFO) was given to patients with DES. DFO mobilized Al from storage sites into blood, increased Al elimination, and reversed some DES symptoms [110, 111]. Further clinical studies showed that DFO can reduce DES mortality [112]. DFO administered to a few AD patients for $>$ three months was claimed to significantly reduce brain $\mathrm{Al}$ when compared to a few non-DFO-treated subjects [113]. To assess the potential for DFO to benefit patients with $A D, 25$ probable AD patients were given $125 \mathrm{mg}(0.19 \mathrm{mmol})$ DFO i.m. twice daily five days weekly for two years [114]. The control groups of probable AD patients received oral lecithin or no 
treatment. A lower mortality and a slower rate of deterioration of activities of daily living were seen in the DFO-treated group. Average cortical brain $\mathrm{Al}$ at autopsy in three humans with $\mathrm{AD}$ treated with a higher dose of DFO was lower than three $\mathrm{AD}$ subjects who received a lower dose, suggesting that DFO-mobilization of $\mathrm{Al}$ from the brain might have contributed to the beneficial effects in these patients [115]. Further studies are necessary to confirm these results and to determine if the beneficial effect of DFO is mediated by $\mathrm{Al}$ and/or Fe chelation, by reduction of oxidative injury, or via some other mechanism.

In animal studies, twice daily i.m. DFO injections considerably reduced the brain $\mathrm{Al}$ concentration in rabbits that were given intracisternal Al maltolate injections [116]. Repeated i.p. DFO injections to rats that had been given a single i.v. Al injection reduced the brain Al $t_{1 / 2}$ from $\sim 150$ to 55 days [26]. These animal studies demonstrate the ability of DFO to accelerate Al clearance from the brain. It is not known if DFO enters the brain to chelate and reduce brain $\mathrm{Al}$ or if the reduction of brain $\mathrm{Al}$ is due to peripheral Al chelation causing redistribution of $\mathrm{Al}$ out of the brain.

There are numerous reports of the onset or exacerbation of encephalopathy and seizures during or shortly after dialysis in Al-loaded humans whose Al accumulation was treated with DFO [117-127]. These adverse effects have been attributed to DFO and to Al mobilization by DFO. Al in CSF increased in a patient whose DES worsened after DFO [126]. To determine if DFO therapy can cause a redistribution of Al to the brain, non-protein bound $\mathrm{Al}$ in brain, liver, and blood ECF was measured in Al-loaded rats after DFO administration. DFO rapidly increased free $\mathrm{Al}$ in the liver, suggesting that it mobilized hepatocyte $\mathrm{Al}$ and formed an $\mathrm{Al}$ :DFO complex, aluminoxamine. An increase in brain ECF Al was also seen which could have been due to chelation of brain $\mathrm{Al}$ or distribution of the Al complexed from the liver into the brain [128]. The efficacy of a low-dose DFO therapeutic regimen has been shown [129].

As DFO is ineffective orally and has significant clinical toxicity, there has been a decades-long search for an orally effective Fe (and Al) chelator. Two orally-absorbed hydroxypyridinone chelators (deferiprone [termed L1 \& CP20] and CP94), which were developed to overcome the lack of oral absorption of DFO, decreased brain Al after i.p. injection [130]. However, little change of brain free Al concentration was seen in Al-loaded rats after injection of these and two other hydroxypyridinone chelators [131]. Repeated oral administration of six hydroxypyridinone chelators to Alloaded rabbits increased Al elimination, primarily in the urine, and decreased blood Al levels. A few of these chelators increased CSF Al, but only one (CP-24) significantly decreased brain Al concentration [132]. A substituted pyrimidine given by gavage was found to reduce brain $\mathrm{Al}$ in Al-loaded mice, although not as effectively as i.p. DFO, providing some hope of the ability to synthesize an orally effective Al chelator [133].

There has been little study of combined therapies to reduce brain Al. Using Al-loaded human brain cell nuclei, the ability of concurrent addition of various chelators to mobilize Al was assessed. Combined ascorbate and Feralex-G (a maltol, glycine and glucosamine complex) was found to be effective, leading the authors to suggest that ascorbate penetrated the nucleus to complex Al, followed by diffusion of the $\mathrm{Al}$ complex to regions where it could be accessed by larger chelators [134]. Oral administration of glutathione paired with Tiron given i.p. reduced oxidative stress in the brain to a greater extent than Tiron alone, but the combination did not enhance the ability of Tiron to reduce brain Al [135]. Five consecutive daily i.p. injections of N-(2hydroxyethyl) ethylenediaminetriacetic acid (HEDTA) to Alloaded rats significantly reduced blood and brain Al nearly to control rat levels, but the addition of oral citrate did not further decrease Al levels [136].

\section{CONCLUSION}

In summary, there is evidence for transporter-mediated influx and efflux of $\mathrm{Al}$ across the $\mathrm{BBB}$, the primary site of brain Al uptake. The glutamate transporter system $\mathrm{Xc}^{-}$has been suggested to mediate brain Al citrate uptake. The role of Al-Tf in brain Al uptake and the underlying mechanism(s) require further research to understand. There is also evidence for carrier-mediated Al efflux from the brain, however, the mechanism(s) have not yet been identified. Identification of the mediating process(es) and factors that influence it (them) might provide insight into ways to reduce the brain's Al burden. It appears that $\mathrm{Al}$ persists in the brain for a long time [with $t_{1 / 2}$ estimates of $20 \%$ of, to beyond, the lifespan], and accumulates over the lifespan, creating the potential to contribute to neurodegenerative disorders. As this is of concern, ways to avoid this would be valuable to understand. Chelation therapy can reduce some of the effects of Al toxicity, probably in the presence of profound Al intoxication. However, chelating agents also appear to have the potential to enhance Al-mediated neurotoxicity due to redistribution of the Al-chelator complex. A better understanding of the factors that impact on the redistribution of the Al-chelator complex to the brain, and identification of chelators that have less or no risk to do this would be valuable. It would be highly desirable to resolve the contentious controversy of the role of, or lack of, $\mathrm{Al}$ as a contributing factor in $\mathrm{AD}$.

\section{ABBREVIATIONS}

$\begin{array}{ll}\mathrm{AD} & =\text { Alzheimer's disease } \\ \mathrm{Al} & =\text { Aluminum } \\ \mathrm{BBB} & =\text { Blood-brain barrier } \\ \mathrm{BMEC} & =\text { Choroid plexus } \\ \mathrm{CP} & =\text { Cerebrospinal fluid } \\ \mathrm{CSF} & =\text { Dialysis encephalopathy syndrome } \\ \mathrm{DES} & =\text { Desferrioxamine } \\ \mathrm{DFO} & =\text { Influx transfer coefficient } \\ \mathrm{ECF} & =\text { Monocarboxylate transporter } \\ \mathrm{K} \text { in } & =\text { Transferrin } \\ \text { MCT } & =\text { Transferrin-receptor } \\ \text { Tf } & =\text { Transferrin-receptor mediated endocytosis } \\ \text { TfR } & =\end{array}$




\section{CONFLICT OF INTEREST}

The author has no financial conflict of interest related to this research.

\section{ACKNOWLEDGEMENTS}

The author's research cited herein was supported by NIH ES K04 174, 1 S15 ES06690 and F 06 TW02343; U.S. EPA, STAR Grant R 825357; The American-Scandinavian Foundation; The Swedish Work Environment Fund; the Burroughs Wellcome Fund; and University of Kentucky College of Pharmacy Biomedical Research Support Grant Funds.

\section{REFERENCES}

[1] Döllken, v. Ueber die wirkung des aluminiums mit besonderer beriicksichtigung der durch das aluminium verursachten lasionen im centralnervensystem. Archiv. Exp. Path. Pharmaco., 1898, 40, 98-120.

[2] Alfrey, A.C. Dialysis encephalopathy syndrome. Annu. Rev. Med., 1978, 29, 93-98.

[3] Crapper, D.R.; Krishnan, S.S.; Dalton, A.J. Brain aluminum distribution in Alzheimer's disease and experimental neurofibrillary degeneration. Science., 1973, 180, 511-513.

[4] Harris, W.R.; Berthon, G.; Day, J.P.; Exley, C.; Flaten, T.P.; Forbes, W.F.; Kiss, T.; Orvig, C.; Zatta, P.F. Speciation of aluminum in biological systems. J. Toxicol. Environ. Health., 1996, 48, 543-568.

[5] Harris, W.R.; Wang, Z.; Hamada, Y.Z. Competition between transferrin and the serum ligands citrate and phosphate for the binding of aluminum. Inorg. Chem., 2003, 42, 3262-3273.

[6] Van Landeghem, G.F.; D'Haese, P.C.; Lamberts, L.V.; Barata, J.D.; De Broe, M.E. Aluminium speciation in cerebrospinal fluid of acutely aluminium- intoxicated dialysis patients before and after desferrioxamine treatment; a step in the understanding of the element's neurotoxicity. Nephrol. Dial. Transplant., 1997, 12, 1692-1698.

[7] Bradbury, M.W. Transport of iron in the blood-brain-cerebrospinal fluid system. J. Neurochem., 1997, 69, 443-454.

[8] Yokel, R.A.; McNamara, P.J. Aluminum toxicokinetics: An updated mini-review. Pharmacol. Toxicoly., 2001, 88, 159-167.

[9] Levin, V.A. Relationship of octanol/water partition coefficient and molecular weight to rat brain capillary permeability. J. Med. Chem., 1980, 23, 682-684.

[10] Winterberg, B.; Bertram, H.; Rolf, N.; Roedig, M.; Kisters, K.; Remmers, S.; Spieker, C.; Zumkley, H. Differences in plasma and tissue aluminum concentrations due to different aluminumcontaining drugs in patients with renal insufficiency and with normal renal function. J. Trace Elem. Electrol. Health Dis., 1987, 1, 69-72.

[11] Drueke, T. Intestinal absorption of aluminum in renal failure. Nephrol. Dial. Transplant., 2002, 17, 13-16.

[12] Fink, D.; Walton, J.; Hotchkis, M.A.C.; Jacobsen, G.E.; Lawson, E.M.; Smith, A.M.; Tuniz, C.; Wilcox, D. First ${ }^{26} \mathrm{Al}$ analyses at the ANTARES AMS Centre: uptake via oral ingestion of ${ }^{26} \mathrm{Al}$ in rats. Nuclear Inst. Meth. Physics Res. B., 1994, 92, 473-477.

[13] Jouhanneau, P.; Raisbeck, G.M.; Yiou, F.; Lacour, B.; Banide, H.; Drüeke, T.B. Gastrointestinal absorption, tissue retention, and urinary excretion of dietary aluminum in rats determined by using ${ }^{26}$ Al. Clin. Chem., 1997, 43, 1023-1028.

[14] Walton, J.; Tuniz, C.; Fink, D.; Jacobsen, G.; Wilcox, D. Uptake of trace amounts of aluminum into the brain from drinking water. NeuroToxicol., 1995, 16, 187-190.

[15] Allen, D.D.; Yokel, R.A. Dissimilar aluminum and gallium permeation of the blood-brain barrier demonstrated by in vivo microdialysis. J. Neurochem., 1992, 58, 903-908.

[16] Allen, D.D.; Orvig, C.; Yokel, R.A. Evidence for energy-dependent transport of aluminum out of brain extracellular fluid. Toxicol., 1995, 98, 31-39.

[17] Xu, Z.C.; Tang, J.P.; Xu, Z.X.; Melethil, S. Kinetics of aluminum in rats. IV: Blood and cerebrospinal fluid kinetics. Toxicol. Lett., 1992, 63, 7-12.
[18]

Yokel, R.A.; Lidums, V.; McNamara, P.J.; Ungerstedt, U. Aluminum distribution into brain and liver of rats and rabbits following intravenous aluminum lactate or citrate: a microdialysis study. Toxicol. Appl. Pharmacol., 1991, 107, 153-163.

[19] Davson, H.; Welch, K.; Segal, M.B. The secretion of the cerebrospinal fluid. In: The physiology and pathophysiology of the cerebrospinal fluid. Churchill Livingstone: New York, 1987; pp. 218-221.

[20] Akeson, M.A.; Munns, D.N. Lipid bilayer permeation by neutral aluminum citrate and by three alpha-hydroxy carboxylic acids. Biochem. Biophys. Acta., 1989, 984, 200-206.

[21] Ohno, K.; Pettigrew, K.D.; Rapoport, S.I. Lower limits of cerebrovascular permeability to nonelectrolytes in the conscious rat. Am. J. Physiol., 1978, 235, H299-H307.

[22] Jagarlamudi, A.; Melethil, S. Aluminum transport across the rat blood-brain barrier: Role of transferrin. Pharmaceut. Res., 1995, 12, S-350.

[23] Radunovic, A.; Bradbury, M.W.B. Transport of aluminium into brain - Its relation to that of gallium and iron. In: Aluminum in chemistry biology and medicine, Nicolini, M.; Zatta, P.F.; Corain, B., Eds.; Harwood Academic Publishers: Switzerland, 1994; Life Chemistry Reports Vol.11, pp. 159-163.

[24] Kobayashi, K.; Yumoto, S.; Nagai, H.; Hosoyama, Y.; Imamura, M.; Masuzawa, S.; Koizumi, Y.; Yamashita, H. ${ }^{26} \mathrm{Al}$ tracer experiment by accelerator mass spectrometry and its application to the studies for amyotrophic lateral sclerosis and Alzheimer's disease. Proc. Japan Acad., 1990, 66, Ser. B, 189-192.

[25] Walker, V.R.; Sutton, R.A.L.; Meirav, O.; Sossi, V.; Johnson, R.; Klein, J.; Fink, D.; Middleton, R. Tissue disposition of ${ }^{26}$ aluminum in rats measured by accelerator mass spectrometry. Clin. Invest. Med., 1994, 17, 420-425.

[26] Yokel, R.A.; Rhineheimer, S.S.; Sharma, P.; Elmore, D. McNamara, P.J. Entry, half-life and desferrioxamine-accelerated clearance of brain aluminum after a single ${ }^{26} \mathrm{Al}$ exposure. Toxicol. Sci., 2001, 64, 77-82.

[27] Yumoto, S.; Nagai, H.; Matsuzaki, H.; Matsumura, H.; Tada, W.; Nagatsuma, E.; Kobayashi, K. Aluminium incorporation into the brain of rat fetuses and sucklings. Brain Res. Bull., 2001, 55, 229 234.

[28] Ueno, M. Molecular anatomy of the brain endothelial barrier: An overview of the distributional features. Curr. Med. Chem., 2007, 14, 1199-1206.

[29] Pardridge, W.M. Blood-brain barrier biology and methodology. $J$. Neurovirol., 1999, 5, 556-569.

[30] Duvernoy, H.; Delon, S.; Vannson, J.L. The vascularization of the human cerebellar cortex. Brain Res. Bull., 1983, 11, 419-80.

[31] Zlokovic, B.V. The blood-brain barrier in health and chronic neurodegenerative disorders. Neuron., 2008, 57, 178-201.

[32] Kerper, L.E.; Ballatori, N.; Clarkson, T.W. Methylmercury transport across the blood-brain barrier by an amino acid carrier. Am. J. Physiol., 1992, 262, R761-R765.

[33] Morris, C.M.; Candy, J.M.; Court, J.A.; Whitford, C.A.; Edwardson, J.A. The role of transferrin in the uptake of aluminium and manganese by the IMR 32 neuroblastoma cell line. Biochem. Soc. Trans., 1987, 15, 498 .

[34] Shi, B.; Haug, A. Aluminum uptake by neuroblastoma cells. $J$. Neurochem., 1990, 55, 551-558.

[35] McGregor, S.J.; Naves, M.L.; Oria, R.; Vass, J.K.; Brock, J.H. Effect of aluminium on iron uptake and transferrin-receptor expression by human erythroleukaemia K562 cells. Biochem. J., 1990, 272, 377-82

[36] McGregor, S.J.; Brock, J.H.; Halls, D. The role of transferrin and citrate in cellular uptake of aluminium. Biol. Metals., 1991, 4, 173175.

[37] Fernandez Menendez, M.J.; Fell, G.S.; Brock, J.H.; Cannata, J.B. Aluminium uptake by intestinal cells: effect of iron status and precomplexation. Nephrol. Dial. Transplant., 1991, 6, 672-674.

[38] Abreo, K.; Jangula, J.; Jain, S.K.; Sella, M.; Glass, J. Aluminum uptake and toxicity in cultured mouse hepatocytes. J. Am. Soc. Nephrol., 1991, 1, 1299-1304.

[39] McGregor, S.J.; Fernandez Menendez, M.J.; Naves, M.L.; Elloriaga, R.; Brock, J.H.; Cannata, J.B. The uptake of aluminum and its effect on iron metabolism in the osteoblast like cell line MG-63. Trace Elem. Electrolytes., 1994, 11, 187-191.

[40] Smans, K.A.; D'Haese, P.C.; Landeghem, G.F.V.; Andries, L.J.; Lamberts, L.V.; Hendy, G.N.; Broe, M.E.D. Transferrin-mediated 
uptake of aluminium by human parathyroid cells results in reduced parathyroid hormone secretion. Nephol. Dial. Transplant., 2000, $15,1328-1336$.

[41] Pérez, G.; Pregi, N.; Vittori, D.; Di Risio, C.; Garbossa, G.; Nesse, A. Aluminum exposure affects transferrin-dependent and independent iron uptake by K562 cells. Biochim. Biophys. Acta., 2005, 1745, 124-130.

[42] Roskams, A.J.; Connor, J.R. Aluminum access to the brain: a role for transferrin and its receptor. Proc. Natl. Acad. Sci., USA 1990, 87, 9024-9027.

[43] Golub, M.S.; Han, B.; Keen, C.L. Aluminum alters iron and manganese uptake and regulation of surface transferrin receptors in primary rat oligodendrocyte cultures. Brain Res., 1996, 719, 72-77.

[44] Morris, C.M.; Candy, J.M.; Oakley, A.E.; Taylor, G.A.; Mountfort, S.; Bishop, H.; Ward, M.K.; Bloxham, C.A.; Edwardson, J.A. Comparison of the regional distribution of transferrin receptors and aluminium in the forebrain of chronic renal dialysis patients. $J$. Neur. Sci., 1989, 94, 295-306.

[45] Hémadi, M.; Miquel, G.; Kahn, P.H.; El Hage Chahine, J.M. Aluminum exchange between citrate and human serum transferrin and interaction with transferrin receptor 1. Biochem., 2003, 42, 3120-3130.

[46] Ha-Duong, N.-T.; Hémadi, M.; Chikh, Z.; Chahine, J.M. Kinetics and thermodynamics of metal-loaded transferrins: transferrin receptor 1 interactions. Biochem. Soc. Trans., 2008, 36, 1422-1426.

[47] Sakajiri, T.; Yamamura, T.; Kikuchi, T.; Ichimura, K.; Sawada, T.; Yajima, H. Absence of binding between the human transferrin receptor and the transferrin complex of biological toxic trace element, aluminum, because of an incomplete open/closed form of the complex. Biol. Trace Elem. Res., 2010, 136, 279-286.

[48] Radunovic, A.; Ueda, F.; Raja, K.B.; Simpson, R.J.; Templar, J.; King, S.J.; Lilley, J.S.; Day, J.P.; Bradbury, M.W. Uptake of 26-Al and $67-\mathrm{Ga}$ into brain and other tissues of normal and hypotransferrinaemic mice. Biometals., 1997, 10, 185-191.

[49] Gregor, J.E.; Powell, H.K.J. Aluminium(III)-citrate complexes: a potentiometric and ${ }^{13}$ C N.M.R. study. Australian J. Chem., 1986, 39, 1851-1864.

[50] Lakatos, A.; Banyai, I.; Decock, P.; Kiss, T. Time-dependent solution speciation of the $\mathrm{Al}^{\mathrm{III}}$-citrate system: potentiometric and NMR studies. Eur. J. Inorg. Chem., 2001, 2001, 461-469.

[51] Ackley, D.C.; Yokel, R.A. Aluminum citrate is transported from brain into blood via the monocarboxylic acid transporter located at the blood-brain barrier. Toxicol., 1997, 120, 89-97.

[52] Ackley, D.C.; Yokel, R.A. Aluminum transport out of brain extracellular fluid is proton dependent and inhibited by mersalyl acid, suggesting mediation by the monocarboxylate transporter (MCT1). Toxicol., 1998, 127, 59-67.

[53] Yokel, R.A.; Wilson, M.; Harris, W.R.; Halestrap, A.P. Aluminum citrate uptake by immortalized brain endothelial cells: Implications for its blood-brain barrier transport. Brain Res., 2002, 930, 101110

[54] Deloncle, R.; Fauconneau, B.; Piriou, A.; Huguet, F.; Guillard, O. Aluminum L-glutamate complex in rat brain cortex: in vivo prevention of aluminum deposit by magnesium D-aspartate. Brain Res., 2002, 946, 247-252.

[55] Nagasawa, K.; Ito, S.; Kakuda, T.; Nagai, K.; Tamai, I.; Tsuji, A.; Fujimoto, S. Transport mechanism for aluminum citrate at the blood-brain barrier: kinetic evidence implies involvement of system $\mathrm{Xc}^{-}$in immortalized rat brain endothelial cells. Toxicol. Lett., 2005, 155, 289-296.

[56] Kim, Y.S.; Lee, M.H.; Wisniewski, H.M. Aluminum induced reversible change in permeability of the blood-brain barrier to [14C]sucrose. Brain Res., 1986, 377, 286-291.

[57] Yenumala, V.; Melethil, S. Aluminum induced changes in bloodbrain barrier permeability to sucrose. Pharmaceut. Res., 1993, 10, S-414.

[58] Kaya, M.; Kalayci, R.; Arican, N.; Kucuk, M.; Elmas, I. Effect of aluminum on the blood-brain barrier permeability during nitric oxide-blockade-induced chronic hypertension in rats. Biol. Trace Elem. Res., 2003, 92, 221-30.

[59] Favarato, M.; Zatta, P.; Perazzolo, M.; Fontana, L.; Nicolini, M. Aluminum (III) influences the permeability of the blood-brain barrier to [14C]sucrose in rats. Brain Res., 1992, 569, 330-335.

[60] Stefanovich, V.; Joo, F. Effect of propentofylline on the biochemical lesion of the rat brain in aluminium-induced neurotoxicity. Metab Brain Dis., 1990, 5, 7-17.
[61] Audus, K.L.; Shinogle, J.A.; Guillot, F.L.; Holthaus, S.R. Aluminum effects on brain microvessel endothelial cell monolayer permeability. Int. J. Pharmaceut., 1988, 45, 249-257.

[62] Deleers, M.; Servais, J.P.; Wulfert, E. Neurotoxic cations induce membrane rigidification and membrane fusion at micromolar concentrations. Biochim. Biophys. Acta, 1986, 855, 271-276.

[63] Banks, W.A.; Kastin, A.J. Aluminium increases permeability of the blood-brain barrier to labelled DSIP and beta-endorphin: possible implications for senile and dialysis dementia. Lancet, 1983, 2, 1227-1229.

[64] Banks, W.A.; Kastin, A.J. The aluminum-induced increase in blood-brain barrier permeability to delta-sleep-inducing peptide occurs throughout the brain and is independent of phosphorus and acetylcholinesterase levels. Psychopharmacol., 1985, 86, 84-89.

[65] Banks, W.A.; Kastin, A.J.; Fasold, M.B. Differential effect of aluminum on the blood-brain barrier transport of peptides, technetium and albumin. J. Pharmacol. Exp. Ther., 1988, 244, 579585.

[66] Banks, W.A.; Kastin, A.J. Aluminum-induced neurotoxicity: alterations in membrane function at the blood-brain barrier. Neurosci. Biobehav. Rev., 1989, 13, 47-53.

[67] Jakovljevic, V.; Banic, B.; Radunovic, A. The effect of aluminium chloride upon the transition of drugs through the blood-brain barrier into the central nervous system. Eur. J. Drug Metab. Pharmacokinetics., 1991, 16, 171-175.

[68] Mudge, D.W.; Johnson, D.W.; Hawley, C.M.; Campbell, S.B.; Isbel, N.M.; Eps, C.L.v.; Petrie, J.J. Does aluminium continue to have a role as a phosphate binder in contemporary practice? $B M C$ Nephrology., 2011, 12.

[69] Peng, J.H.; Xu, Z.C.; Xu, Z.X.; Parker, J.C., Jr.; Friedlander, E.R.; Tang, J.P.; Melethil, S. Aluminum-induced acute cholinergic neurotoxicity in rat. Molecular and Chemical Neuropath., 1992, 17, 79-89.

[70] Kapaki, E.N.; Zournas, C.P.; Segdistsa, I.T.; Xenos, D.S.; Papageorgiou, C.T. Cerebrospinal fluid aluminum levels in Alzheimer's disease. Biol. Psychiatry., 1993, 33, 679-681.

[71] Jagannatha Rao, K.; Rao, R.; Shanmugavelu, P.; Menon, R. Trace elements in the cerebrospinal fluid in Alzheimer's disease. Alz Rep., 1999, 2, 333-338.

[72] Alimonti, A.; Bocca, B.; Pino, A.; Ruggieri, F.; Forte, G.; Sancesario, G. Elemental profile of cerebrospinal fluid in patients with Parkinson's disease. J. Trace Elem. Med. Biol., 2007, 21, 234241.

[73] Bodian, D.; Howe, H.A. The rate of progression of poliomyelitis virus in nerves. Bull. Johns Hopkins Hospital., 1941, 69, 79-85.

[74] De Lorenzo, A. The olfactory neuron and the blood-brain barrier. In: Taste and smell in vertebrates. Wolstenholme, G.; Knight, J., Eds.; Churchhill: London, 1970; pp. 151-176.

[75] Oberdörster, G.; Sharp, Z.; Atudorei, V.; Elder, A.; Gelein, R.; Kreyling, W.; Cox, C. Translocation of inhaled ultrafine particles to the brain. Inhal. Toxicol., 2004, 16, 437-445.

[76] Elder, A.; Gelein, R.; Silva, V.; Feikert, T.; Opanashuk, L.; Carter, J.; Potter, R.; Maynard, A.; Ito, Y.; Finkelstein, J.; Oberdörster, G. Translocation of inhaled ultrafine manganese oxide particles to the central nervous system. Environ. Health Perspect., 2006, 114, 1172-1178.

[77] Fechter, L.D.; Johnson, D.L.; Lynch, R.A. The relationship of particle size to olfactory nerve uptake of a non-soluble form of manganese into brain. Neurotoxicol., 2002, 23, 177-183.

[78] Dorman, D.C.; Brenneman, K.A.; McElveen, A.M.; Lynch, S.E.; Roberts, K.C.; Wong, B.A. Olfactory transport: a direct route of delivery of inhaled manganese phosphate to the rat brain. $J$. Toxicol. Environ. Health A., 2002, 65, 1493-1511.

[79] Henriksson, J.; Tallkvist, J.; Tjälve, H. Uptake of nickel into the brain via olfactory neurons in rats. Toxicol. Lett., 1997, 91, 153162.

[80] Ohno, M.; Amano, R.; Enomoto, S. Multitracer screening: search for elements delivered directly to brain via nostrils. Mouse experiments. In: Proceedings of the Fifth Workshop on Environmental Radioactivity, KEK-Proceedings-2004-8, 2004; pp. 291-297.

[81] Kanayama, Y.; Enomoto, S.; Irie, T.; Amano, R. Axonal transport of rubidium and thallium in the olfactory nerve of mice. Nucl. Med. Biol., 2005, 32, 505-512.

[82] Tjälve, H.; Henriksson, J. Uptake of metals in the brain via olfactory pathways. NeuroToxicol., 1999, 20, 181-195. 
[83] Lewis, J.; Bench, G.; Myers, O.; Tinner, B.; Staines, W.; Barr, E.; Divine, K.K.; Barrington, W.; Karlsson, J. Trigeminal uptake and clearance of inhaled manganese chloride in rats and mice. NeuroToxicol., 2005, 26, 113-123.

[84] Chow, H.S.; Chen, Z.; Matsuura, G.T. Direct transport of cocaine from the nasal cavity to the brain following intranasal cocaine administration in rats. J. Pharmaceut. Sci., 1999, 88, 754-758.

[85] Lum, K.R.; Betteridge, J.S.; Macdonald, R.R. The potential availability of $\mathrm{P}, \mathrm{Al}, \mathrm{Cd}, \mathrm{Co}, \mathrm{Cr}, \mathrm{Cu}, \mathrm{Fe}, \mathrm{Mn}, \mathrm{Ni}, \mathrm{Pb}$ and $\mathrm{Zn}$ in urban particulate matter. Environ. Tech. Lett., 1982, 3, 57-62.

[86] Perl, D.P.; Good, P.F. Uptake of aluminium into central nervous system along nasal-olfactory pathways. Lancet, 1987, 1, 1028.

[87] Lewis, J.L.; Hahn, F.F.; Dahl, A.R. Transport of inhaled toxicants to the central nervous system. Characteristics of a nose-brain barrier. In: The Vulnerable Brain and Environmental Risks, Volume 3: Toxins in Air and Water; Isaacson, R.L.; Jensen, K.F., Eds.; Plenum Press: New York, 1994; pp. 77-103.

[88] Katz, R.N.; Good, P.F.; Kaputsin, A.A.; Hsu, A.; Perl, D.P. Widespread autofluorescent granulomas in the rabbit central nervous system (CNS) following intranasal exposure to a lipophilic aluminum-containing compound aluminum flavonol. In: 22nd Annual Meeting of The Society for Neuroscience: Anaheim, California, USA, 1992; pp. 1610

[89] Divine, K.K.; Lewis, J.L.; Grant, P.G.; Bench, G. Quantitative particle-induced X-ray emission imaging of rat olfactory epithelium applied to the permeability of rat epithelium to inhaled aluminum. Chem. Res. Toxicol., 1999, 12, 575-581.

[90] Zatta, P.; Favarato, M.; Nicolini, M. Deposition of aluminum in brain tissues of rats exposed to inhalation of aluminum acetylacetonate. Neuroreport, 1993, 4, 1119-1122.

[91] Corona, C.; Porcario, C.; Martucci, F.; Iulini, B.; Manea, B.; Gallo, M.; Palmitessa, C.; Maurella, C.; Mazza, M.; Pezzolato, M.; Acutis, P.; Casalone, C. Olfactory system involvement in natural scrapie disease. J. Virol., 2009, 83, 3657-67.

[92] Alfrey, A.C.; Hegg, A.; Craswell, P. Metabolism and toxicity of aluminum in renal failure. Am. J. Clin. Nutr., 1980, 33, 1509-1516. Crapper, D.R.; Krishnan, S.S.; Quittkat, S. Aluminium, neurofibrillary degeneration and Alzheimer's disease. Brain, 1976, 99, 67-80.

[94] Yokel, R.A. Persistent aluminum accumulation after prolonged systemic aluminum exposure. Biol. Trace Elem. Res., 1983, 5, 467474.

[95] Traub, R.D.; Rains, T.C.; Garruto, R.M.; Gajdusek, D.C.; Gibbs, C.J. Brain destruction alone does not elevate brain aluminum. Neurol., 1981, 31, 986-990.

[96] Zumkley, H.; Bertram, H.P.; Brandt, M.; Rödig, M.; Spieker, C. Magnesium, aluminum and lead in various brain areas. Trace Substances Environ. Health, 1986, 20, 29-35.

[97] Speziali, M.; Orvini, E. Metals distribution and regionalization in the brain. In: Metal Ions and Neurodegenerative Disorders. Zatta, P, Ed; World Scientific Publishing Co. Pte. Ltd.: Singapore, Singapore, 2003; pp. 15-65.

[98] Shimizu, H.; Mori, T.; Koyama, M.; Sekiya, M.; Ooami, H. [A correlative study of the aluminum content and aging changes of the brain in non-demented elderly subjects]. Japan. J. Geriatrics, 1994, $31,950-960$

[99] Massie, H.R.; Aiello, V.R.; Iodice, A.A. Changes with age in copper and superoxide dismutase levels in brains of C57BL/6J mice. Mech. Ageing Dev., 1979, 10, 93-99.

[100] Bartzokis, G.; Beckson, M.; Hance, D.B.; Marx, P.; Foster, J.A.; Marder, S.R. MR evaluation of age-related increase of brain iron in young adult and older normal males. Magn. Reson. Imaging, 1997, $15,29-35$

[101] Zecca, L.; Gallorini, M.; Schunemann, V.; Trautwein, A.X.; Gerlach, M.; Riederer, P.; Vezzoni, P.; Tampellini, D. Iron, neuromelanin and ferritin content in the substantia nigra of normal subjects at different ages: consequences for iron storage and neurodegenerative processes. J. Neurochem., 2001, 76, 1766-1773.

[102] Markesbery, W.R.; Ehmann, W.D.; Alauddin, M.; Hossain, T.I.M. Brain trace element concentrations in aging. Neurobiol. Aging, 1984, 5, 19-28.

[103] Morita, A.; Kimura, M.; Itokawa, Y. The effect of aging on the mineral status of female mice. Biol. Trace Elem. Res., 1994, 42, 165-177.
[104] McDermott, J.R.; Smith, A.I.; Iqbal, K.; Wisniewski, H.M. Brain aluminum in aging and Alzheimer disease. Neurol., 1979, 29, 809814.

[105] Roider, G.; Drasch, G. Concentration of aluminum in human tissues - investigations on an occupationally non-exposed population in Southern Bavaria (Germany). Trace Elem. Electrolytes, 1999, 16, 77-86.

[106] Krewski, D.; Yokel, R.A.; Nieboer, E.; Borchelt, D.; Cohen, J.; Harry, J.; Kacew, S.; Lindsay, J.; Mahfouz, A.M.; Rondeau, V. Human health risk assessment for aluminium, aluminium oxide, and aluminium hydroxide. J. Toxicol. Environ. Health, Part B: Crit. Rev., 2007, 10, Suppl 1, 1-269.

[107] Yumoto, S.; Nagai, H.; Imamura, M.; Matsuzaki, H.; Hayashi, K.; Masuda, A.; Kumazawa, H.; Ohashi, H.; Kobayashi, K. ${ }^{26} \mathrm{Al}$ uptake and accumulation in the rat brain. Nucl. Inst. Meth. Physics Res. B., 1997, 123, 279-282.

[108] Yumoto, S.; Nagai, H.; Kakimi, S.; Matsuzaki, H. 26Al incorporation into the brain of rat fetuses through the placental barrier and subsequent metabolism in postnatal development. Nucl. Inst. Meth. Physics Res. B., 2010, 268, 1328-1330.

[109] Priest, N.D. The biological behaviour and bioavailability of aluminium in man, with special reference to studies employing aluminium-26 as a tracer: review and study update. J. Environ. Monit., 2004, 6, 375-403.

[110] Ackrill, P.; Ralston, A.J.; Day, J.P.; Hodge, K.C. Successful removal of aluminium from patient with dialysis encephalopathy. Lancet, 1980, 2, 692-3.

[111] Arze, R.S.; Parkinson, I.S.; Cartlidge, N.E.; Britton, P.; Ward, M.K. Reversal of aluminium dialysis encephalopathy after desferrioxamine treatment. Lancet, 1981, 2, 1116.

[112] Milne, F.J.; Sharf, B.; Bell, P.D.; Meyers, A.M. Low aluminium water, desferrioxamine, and dialysis encephalopathy. Lancet, 1982, 2, 502 .

[113] Kruck, T.P.; McLachlan, D.R. Aluminum as a pathogenic factor in senile dementia of the Alzheimer type: ion specific chelation. Prog. Clin. Biol. Res., 1989, 317, 1155-1167.

[114] Crapper McLachlan, D.R.; Dalton, A.J.; Kruck, T.P.A.; Bell, M.Y.; Smith, W.L.; Kalow, W.; Andrews, D.F. Intramuscular desferrioxamine in patients with Alzheimer's disease. Lancet, 1991, 337, 1304-1308

[115] Kruck, T.P.A.; Krishnan, S.S.; McLachlan, D.R.C.; Percy, M.E. Intramuscular injection of desferrioxamine lowers brain aluminum concentration in patients with Alzheimer disease. Metal Ions Biol. Med., 2002, 7, 189-192.

[116] Huang, Y.; Savory, J.; Herman, M.M.; Nicholson, J.R.; Reyes, M.R.; Boyd, J.C.; Wills, M.R. Quantitative evaluation of Al maltolate-induced neurodegeneration with subsequent $\mathrm{Al}$ removal by desferrioxamine treatment. NeuroToxicol., 1995, 16, 291-296.

[117] Stivelman, J.; Hakim, R.; Schulman, G.; Kelleher, S.; Lazarus, J.M. Excerbation of possible dialysis encephalopathy with deferoxamine. Am. J. Kidney Dis., 1985, 6, A21.

[118] Ackrill, P.; Ralston, A.J.; Day, J.P. Role of desferrioxamine in the treatment of dialysis encephalopathy. Kidney Int. Suppl., 1986, 18, S104-7.

[119] Swartz, R.; Dombrouski, J.; Burnatowska-Hledin, M.; Mayor, G. Microcytic anemia in dialysis patients: reversible marker of aluminum toxicity. Am. J. Kidney Dis., 1987, 9, 217-23.

[120] Davenport, A.; Ahmad, R. Grand mal fitting in a patient on regular haemodialysis treatment and receiving desferrioxamine therapy. Scand. J. Urol. Nephrol., 1988, 22, 159-60.

[121] Sherrard, D.J.; Walker, J.V.; Boykin, J.L. Precipitation of dialysis dementia by deferoxamine treatment of aluminum-related bone disease. Am. J. Kidney Dis., 1988, 12, 126-30.

[122] Altmann, P.; Dhanesha, U.; Hamon, C.; Cunningham, J.; Blair, J.; Marsh, F. Disturbance of cerebral function by aluminium in haemodialysis patients without overt aluminium toxicity. Lancet, 1989, 2, 7-12.

[123] Canavese, C.; Pacitti, A.; Segoloni, G.; Thea, A.; D'Amicone, M.; Stratta, P.; Rossi, P.; Sabbioni, E.; Pietra, R.; Constantini, S.; et al. Clinical and histological results of long-term management of aluminium overloading in uraemic patients with desferrioxamine. J. Trace Elem. Electrolytes Health Dis., 1989, 3, 17-23.

[124] Lillevang, S.T.; Pedersen, F.B. Exacerbation of aluminium encephalopathy after treatment with desferrioxamine. Nephrol. Dial. Transplant., 1989, 4, 676. 
[125] McCauley, J.; Sorkin, M.I. Exacerbation of aluminium encephalopathy after treatment with desferrioxamine. Nephrol. Dial. Transplant., 1989, 4, 110-114.

[126] Ellenberg, R.; King, A.L.; Sica, D.A.; Posner, M.; Savory, J. Cerebrospinal fluid aluminum levels following deferoxamine. Am. J. Kidney Dis., 1990, 16, 157-159

[127] Ogborn, M.R.; Dorcas, V.C.; Crocker, J.F. Deferoxamine and aluminum clearance in pediatric hemodialysis patients. Pediatr. Nephrol., 1991, 5, 62-4.

[128] Yokel, R.A.; Lidums, V.; Ungerstedt, U. Aluminum mobilization by desferrioxamine assessed by microdialysis of the blood, liver and brain. Toxicol., 1991, 66, 313-324.

[129] Kan, W.C.; Chien, C.C.; Wu, C.C.; Su, S.B.; Hwang, J.C.; Wang, H.Y. Comparison of low-dose deferoxamine versus standard-dose deferoxamine for treatment of aluminium overload among haemodialysis patients. Nephrol. Dial. Transplant., 2010, 25, 16041608.

[130] Florence, A.L.; Gauthier, A.; Ward, R.J.; Crichton, R.R. Influence of hydroxypyridones and desferrioxamine on the mobilization of aluminium from tissues of aluminium-loaded rats. Neurodegeneration, 1995, 4, 449-455.

[131] Yokel, R.A. Aluminum chelation by 3-hydroxypyridin-4-ones in the rat demonstrated by microdialysis. Biol. Trace Elem. Res., 1996, 53, 193-203.
[132] Yokel, R.A.; Meurer, K.A.; Hong, C.B.; Dickey, K.M.; Skinner, T.L.; Fredenburg, A.M. Short-term oral 3-hydroxypyridin-4-one dosing increases aluminum excretion and partially reverses aluminum-induced toxicity in the rabbit independent of chelator lipophilicity. Drug Metab. Disp., 1997, 25, 182-190.

[133] Missel, J.R.; Schetinger, M.R.; Gioda, C.R.; Bohrer, D.N.; Pacholski, I.L.; Zanatta, N.; Martins, M.A.; Bonacorso, H. Morsch, V.M. Chelating effect of novel pyrimidines in a model of aluminum intoxication. J. Inorg. Biochem., 2005, 99, 1853-1857.

[134] Kruck, T.P.; Cui, J.G.; Percy, M.E.; Lukiw, W.J. Molecular shuttle chelation: the use of ascorbate, desferrioxamine and Feralex-G in combination to remove nuclear bound aluminum. Cell Mol. Neurobiol., 2004, 24, 443-59.

[135] Sharma, P.; Ahmad Shah, Z.; Kumar, A.; Islam, F.; Mishra, K.P. Role of combined administration of Tiron and glutathione against aluminum-induced oxidative stress in rat brain. J. Trace Elem. Med. Biol., 2007, 21, 63-70.

[136] Flora, S.J.; Mehta, A.; Satsangi, K.; Kannan, G.M.; Gupta, M. Aluminum-induced oxidative stress in rat brain: response to combined administration of citric acid and HEDTA. Comp. Biochem. Physiol. C Toxicol. Pharmacol. 2003, 134, 319-328. 